\title{
A Comparison Between the Performance of S. Cerevisiae Cells Immobilized in Nata de Coco Biocellulose and Calcium Alginate During Continuous Bioethanol Production
}

\author{
Charlimagne M. Montealegre, Emerson R. Dionisio, Lawrence V. Sumera, Jay R T. Adolacion, and \\ Rizalinda L. De Leon
}

\begin{abstract}
The performance of Nata de coco (NDC) and Calcium alginate (CA) as an immobilization medium for Saccharomyces cerevisiae cells are compared in terms of production rate and conversion. $S$. cerevisiae cells are immobilized in NDC and CA beads using a cell suspension with an average approximate live cell density of $232.1 \pm 1.5$ cells $/ \mathrm{mL}$. The biocatalysts NDC and $C A$ are charged into horizontal fermentation reactors. A centrifugal pump and manifold is used to control the flow rate to a desired flow rate of $9 \mathrm{~mL} / \mathrm{hr}$. Samples are collected every 12 hours and tested for ethanol by gas chromatography and glucose concentration by colorimetry. The average effluent ethanol concentration, productivity, conversion and yield during continuous fermentation in NDC are $5.093 \%$ by volume, $52.329 \mathrm{~mL} / \mathrm{hr}, 0.7779$ and 0.7620 , respectively. One-way ANOVA showed that the immobilization medium has no significant effect on the parameters under consideration i.e. the effluent ethanol concentration, productivity yield and conversion of NDC and CA immobilized cells are statistically equal. The study showed that the NDC biocatalyst performs equally well in the conditions optimized for $\mathrm{CA}$ biocatalyst. The structural strength and cost effectiveness of Nata de Coco makes it a very promising immobilization medium for continuous bioethanol production.
\end{abstract}

Index Terms-Biocellulose, calcium alginate, cell immobilization, continuous fermentation

\section{INTRODUCTION}

Ethanol can be produced from hydrocarbons or carbohydrates by ethylene hydration or fermentation, respectively. Ethylene hydration is the commercially preferred method of production especially for industrial applications while for beverages it is produced via yeast cell fermentation. Threats to the environment and depletion of fossil fuels have encouraged the use of ethanol as a gasoline

Manuscript received July 7, 2012; revised August 12, 2012.

C. M. Montealegre is an instructor in the Department of Chemical Engineering, College of Engineering, University of the Philippines, 1101 Diliman Quezon City (e-mail: charliemontealegre@gmail.com).

E. R. Dionisio and L. V. Sumera are graduates of the University of the Philippines, Diliman Quezon City (e-mail: erdionisio@gmail.com, lawrence.sumera@gmail.com).

J. T. Adolacion is an instructor in the Department of Chemical Engineering, University of the Philippines Diliman Quezon City (e-mail: jayr.adolacion@coe.upd.edu.ph).

R. L. De Leon is with the Fuels, Energy and Thermal Systems Laboratory, Department of Chemical Engineering, College of Engineering, University of the Philippines, Diliman, Quezon City, NCR 1100, Philippines (e-mail: rldeleon@up.edu.ph). additive, specifically bioethanol. Low production rates render batch fermentation processes for biofuel production costly and impractical. Continuous fermentation systems offer important economic advantages and significantly improve production rate. In freely suspended cell systems, continuous operation is limited to low flow rates to prevent entrainment of yeast cells in the effluent resulting to a decrease or complete loss of cells. Cell immobilization provides structural support to the cells promoting operation at higher flow rates. Immobilized cells may also have decreased sensitivity to sudden fluctuations in operating parameters such as $\mathrm{pH}$, dissolved oxygen, and osmolality, thereby increasing the range of operating conditions. This increased adaptability is promising for optimization but such changes in properties depend on the method of immobilization.

Immobilization methods are generally classified as active, involving chemical agents, and passive which do not require addition of chemicals. Under passive methods are flocculation, colonization and adsorption. Flocculation of cells occurs for several reasons including growth, interaction with other cells and as a response to their surroundings. Flocculation may be induced by chemically modifying the cells' immediate environment. In colonization, porous biomass support particles are used to provide interconnecting voids within an open network of matrix support materials.

In surface adsorption, cells adhere to surfaces due to electrostatic forces hence immobilized. Thus chemical reagents are unnecessary and the cost of immobilization is low but there is a possibility for cell detachment with changes in the environment of the cell and the immobilization medium. Yeast cells are adsorbed on the surface of Nata de Coco (NDC) which is a highly hydrophilic and strong material with a young's modulus comparable to aluminum [1]. Studies on optimization of the immobilization based on initial cell concentration and time of immobilization process has been reported in the literature [2].

Active immobilization methods inlcude covalent bonding, crosslinking and entrapment or encapsulation. Covalent bonding requires chemical modification of the immobilization medium which requires chemicals and additional cost of immobilization. In crosslinking, chemical agents are used to bind the cells and the immobilization medium. These chemical agents, such as glutaraldehyde, find limited applications in cell immobilization due to their toxicity. In matrix encapsulation, cells are trapped in a 
polymer matrix of materials such as alginate and carrageenan. Sodium alginate forms a viscous solution with water which hardens when reacted with some metal salts like calcium. The alginate solution can be mixed with the cell suspension, reacted with a calcium solution and trap cells in the calcium alginate (CA) matrix. Entrapment in CA is commonly used in studies with ethanol fermentation due to "the requirement for mild conditions and the simplicity of the used procedure" [3].

There are several disadvantages in immobilization with CA. Carbon dioxide is a fermentation by-product which damages gel particles. Other disadvantages are "diffusion limitations of nutrients, metabolites and oxygen due to the gel matrix and the high cell densities in the gel beads, the chemical and physical instability of the gel and the non-regenerability of the beads, making this immobilization type rather expensive" [4]. Carbon dioxide production also decreases the working volume of the reactor thereby reducing its fermentative capacity and the pressure developed in vertical reactors results in disintegration of the CA immobilized cells. Horizontal bioreactors have a low height to length ratio thus when packed with biocatalysts, the shallow depth minimizes static pressure developed in the reactor. These reactors normally have a head space which collects gaseous products. The gaseous products can easily exit the catalyst bed with minimal accumulation and disturbance to the bed. Several studies showed that a horizontal reactor decreased gas hold up and that ethanol production rate is 1.5 times higher relative to a vertical configuration [5].

Cellulose is among the most abundant material on earth. Plant cellulose is usually bound to lignin and other plant tissue making pure cellulose from plants difficult to obtain. Nata de Coco or coconut gel is a form of cellulose produced by the bacteria Acetobacter Xylinum. Both plant cellulose and $\mathrm{BC}$ are made up of glucose units with a $\beta-1,4$ linkage as shown in Fig. 1, but BC has several different properties including a high purity.

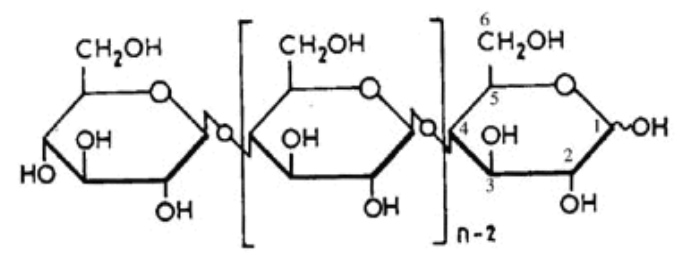

Fig. 1. Chemical structure of plant cellulose and biocellulose.

Biocellulose is "free of lignin and hemicelluloses with high degree of crystallinity [70\% to $90 \%$ ]" [6]. Unlike cellulose, there is no need for $\mathrm{BC}$ to undergo delignification and other energy and resource intensive processes, thus $\mathrm{BC}$ is able to retain structural integrity. It has a high degree of polymerization, having longer polymer chains which give it more strength. A. xylinum is capable of producing BC with a diameter 100 times smaller than cellulose [1]. Consequently, the surface area of BC is much greater than the surface area of cellulose making it very hydrophilic. "Depending on synthetic conditions, it may have a water holding capacity ranging from 60 to 700 times its dry weight" [7]. Aside from all these aforementioned properties, existing properties of biocellulose can be modified or new properties may be introduced into the material by including other molecules/chemicals within the BC's structure. An example of which is adding carboxymethylcellulose which increases water capacity up to 1000 times its dry weight [7]. With its current properties and the high hydrophillicity, NDC is a very good candidate as a support material for the immobilization of yeast. Immobilization in NDC also minimizes the mass transfer limitations of the reactant to the cells since the cells are adsorbed in the surface. On the other hand, this surface availability carries the consequence of exposing the cells to the toxic ethanol product.

Several studies have been performed for continuous bioethanol production using different immobilization materials, parameters and operating conditions. "In fact, almost all the methods of immobilization, namely, gel entrapment, adsorption on the surfaces of the various carriers, cross linking were tried for alcohol fermentation" [3]. Different parameters have been studied but the relative performance of the materials is hard to determine due to differences in feed, broth, cell suspension and other parameters.

In this study, the performance of NDC and CA immobilized $S$. cerevisiae cells are compared during continuous fermentation in a horizontal bioreactor in terms of effluent ethanol concentration, ethanol production rate, conversion and yield.

\section{Materials AND Methodology}

\section{A. Yeast Cell Source}

Commercially available Eagle $₫$ Instant dry yeast was used as the source of $S$. cerevisiae cells. The cell density in the suspension was determined by dissolving varying amounts of dry yeast in $10 \mathrm{~mL}$ of distilled water at $30 \mathrm{C}$ and counting by hemocytometry. A linear correlation was observed in the cell density-mass plot and the mass of dry yeast corresponding to the desired cell density was determined. A factor of $80 \%$ was used to consider viability of cells as suggested in literature [8].

\section{B. Cell Suspension}

The cell suspension was prepared by combining $10 \mathrm{~g}$ of glucose, $5 \mathrm{~g}$ peptone, $3 \mathrm{~g}$ dextrose, $3 \mathrm{~g}$ yeast extract, $10 \mathrm{~mL}$ of pH 4 acetic acid-acetate buffer and enough distilled water. The mixture was autoclaved at $121^{\circ} \mathrm{C}$ for 15 minutes; afterwards it was cooled to approximately $40^{\circ} \mathrm{C}$ before adding $4.1597 \mathrm{~g}$ dry yeast and dilution to 1 Liter.

\section{Fermentation Broth Composition}

One liter of the fermentation broth was prepared by mixing $100 \mathrm{~g}$ glucose, $5 \mathrm{~g}$ yeast extract, $5 \mathrm{~g}$ (NH4)2SO4, $0.125 \mathrm{~g}$ K2HPO4, $0.875 \mathrm{~g} \mathrm{KH} 2 \mathrm{PO} 4,0.1 \mathrm{~g} \mathrm{NaCl}, 0.5 \mathrm{~g} \mathrm{MgSO} 4 \cdot 7 \mathrm{H} 2 \mathrm{O}$, $0.1 \mathrm{~g} \mathrm{CaCl} 2 \cdot 2 \mathrm{H} 2 \mathrm{O}$ and $10 \mathrm{~mL}$ of $\mathrm{pH} 4$ acetic acid-acetate buffer $500 \mathrm{~mL}$ of distilled water was added prior to autoclaving. After autoclaving the broth was diluted to $1 \mathrm{~L}$ using distilled water. The final glucose concentration is 100 $\mathrm{g} / \mathrm{L}$.

\section{Immobilization Media (Nata de Coco \& Calcium Alginate)}

Unsweetened NDC procured from the local market was cut into $1 \times 1 \times 1 \mathrm{~cm}$ cubes, washed and soaked for one week to remove any residual sugar and impurities. NDC was then 
autoclaved at $121^{\circ} \mathrm{C}$ for 15 minutes. Then, 200 grams of the autoclaved NDC was mixed with 1 liter of cell suspension with an initial cell density of $200 \times 10^{6}$ cells $/ \mathrm{mL}$ at $200 \mathrm{rpm}$ for $5 \mathrm{hrs}$. The detailed immobilization method is described in literature [2], however the incubation step is skipped.

For immobilization in sodium alginate beads, Analytical Reagent grade Sodium Alginate from Sigma Aldrich was used. Two and a half grams of analytical Reagent grade Sodium Alginate was dissolved in $125 \mathrm{~mL}$ of distilled water and mixed with $125 \mathrm{~mL}$ of cell suspension. A $10-\mathrm{mL}$ glass pipette was used to drop the Alginate into $500 \mathrm{~mL}$ of calcium chloride solution containing $30 \mathrm{~g}$ of calcium chloride. CA beads were soaked in calcium chloride solution for $22 \mathrm{hrs}$ as suggested in literature [9].

After immobilization, the biocatalysts NDC and CA were washed with distilled water and weighed. The volume of biocatalyst required to give a void fraction of 0.7 is calculated and the density of the biocatalysts are used to determine the required mass for each reactor.

\section{E. Continuous Fermentation}

A horizontal bioreactor with a total dimension of $320 \times 30$ $\times 50 \mathrm{~mm}$ was constructed from plexi-glass and was packed with the biocatalysts to a void fraction of 0.7 . An over flow weir maintained liquid height to approximately $25 \mathrm{~mm}$ with a working dimension of $300 \times 30 \times 25 \mathrm{~mm}$. Fermentation broth was fed into the reactor at a rate of $9 \mathrm{~mL} / \mathrm{hr}$ to give a residence time of $25 \mathrm{hrs}$. A constant temperature bath was used to maintain the temperature at $30^{\circ} \mathrm{C}$. A schematic diagram of the experimental set up is show in Fig. 2.

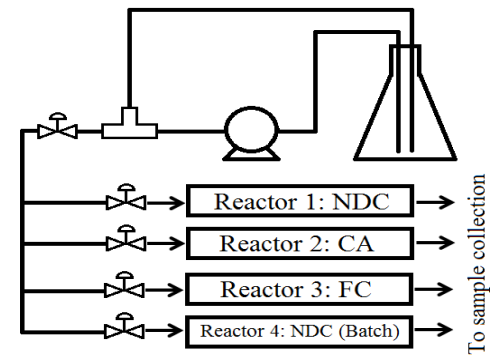

Fig. 2. The experimental set-up is composed of the fermentation broth reservoir, a centrifugal pump, control valves and the reactors.

The fermentation broth was stored in a large sealed flask. The fermentation broth is pumped to the reactors using a centrifugal pump and a manifold to control the flow rate to 9 $\mathrm{mL} / \mathrm{hr}$. Due to limitations in the pump used, some of the flow is redirected back to the fermentation broth reservoir to achieve the desired flow rate. Four fermentation set-ups were run simultaneously over a 72 hour period. The first reactor contains yeast cells immobilized in NDC, in the second one the cells are immobilized in CA. The third reactor contains suspended, non-immobilized or free cells (FC) and in the fourth reactor is a control where cells are immobilized in NDC but is in batch operation. Batch fermentation was performed for the first 12 hours to approach the constant outlet concentration faster. This was followed by continuous fermentation until the $72^{\text {nd }}$ hour except for the control in batch run. Samples were collected every 12 hours, stored, sealed and frozen in vials prior to testing.

\section{F. Glucose and Ethanol Measurement}

Residual glucose in the samples were measured using colorimetry with 3,5-dinitrosalicylic acid and a glucose internal standard at $575 \mathrm{~nm}$. Details of the procedure are described elsewhere [10].

Ethanol concentration in the samples was measured using an HP 5890 series II Gas Chromatograph equipped with flame ionization detector and a HP-5 Crosslinked 5\% PhMe Silicone column. Helium was used as carrier gas with isopropanol as internal standard and an oven temperature of $40^{\circ} \mathrm{C}$. This methodology is based on Standard Biomass Analytical methods provided by the National Renewable Energy Laboratory operated by the Midwest Research Institute for the Department of Energy [11].

\section{G. Statistical Analysis}

One-way Analysis of Variance (ANOVA) with three levels corresponding to free cell (FC), NDC immobilized and $\mathrm{CA}$ immobilized cells is used in the determination of the significance of immobilization medium to the average effluent ethanol concentration, productivity, yield and conversion during continuous operation.

\section{RESULTS AND DISCUSSION}

\section{A. Cell Density-Mass Correlation}

The cell density resulting from $10-\mathrm{mL}$ solutions of varying amounts of dry yeast is plotted in Fig. 3.

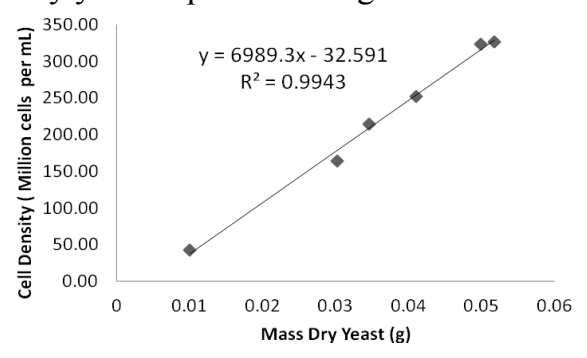

Fig. 3. Plot of cell density versus amount of dry yeast.

A line was fitted to relate cell density with mass of dry yeast. A slope of 6989.3 million cells $/ \mathrm{mL} / \mathrm{g}$ dry yeast was determined. The correlation factor has a value of 0.9943 as shown in the plot which supports the goodness of the linear fit. It should be noted that at zero grams of dry yeast the theoretical cell density is zero but this is inconsistent with what is predicted by the correlation. However, the correlation should be valid for the range upon which it is based. The equation of the line easily relates the necessary amount of dry yeast needed to achieve the desired cell density of $200 \times 10^{6}$ cells/mL required by the cell suspension; the amount of dry yeast necessary to make a $10-\mathrm{mL}$ solution is 0.03328 grams. Taking into consideration $80 \%$ cell viability [8], 4.160 grams of dry yeast is required to make $1 \mathrm{~L}$ of this solution.

The simplicity of the previously presented process is also a disadvantage as it does not give the actual cell density of the cell suspensions. However such simplicity is sufficient for the goals of this study, i.e. to determine the relative performance of the immobilization medium NDC and CA.

\section{B. Ethanol and Glucose Concentration Profiles}

The average actual reactor operation conditions are summarized in Table I. 
TABLE I: SUMMARY OF STEADY STATE VALUES OF PARAMETERS

\begin{tabular}{|l|c|c|c|c|}
\hline \multicolumn{1}{|c|}{ Parameter } & Theoretical & Free cell & NDC & CA \\
\hline $\begin{array}{l}\text { Flow rate } \\
\text { (mL/hr) }\end{array}$ & 9 & 12.16 & 10.38 & 11.43 \\
\hline $\begin{array}{l}\text { Void } \\
\text { fraction }\end{array}$ & 0.7 & 1 & 0.7402 & 0.7730 \\
\hline $\begin{array}{l}\text { Residence } \\
\text { Time (hr) }\end{array}$ & 25 & 23.01 & 19.87 & 19.16 \\
\hline
\end{tabular}

There is a slight variation in the averaged operating parameters relative to the theoretical. Of the three parameters in table I, the most important parameter to consider is the residence time. The residence time in NDC immobilized cells is higher by $0.72 \mathrm{hr}$ or is $3.61 \%$ higher than the residence time in CA due to the difference in the actual feed flow rate to the reactors.

The ethanol concentrations are measured at different durations for each run and are averaged. The concentration is plotted as a function of time as shown in fig. 4 .

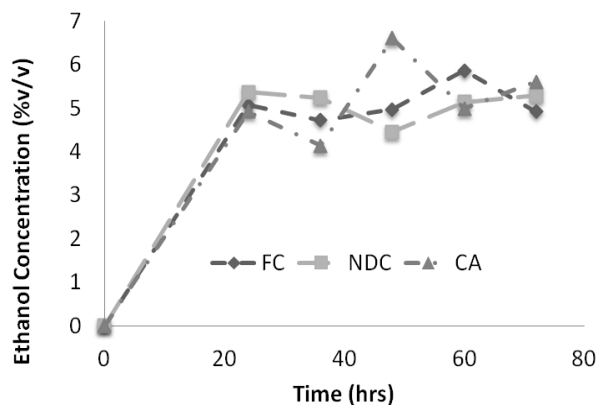

Fig. 4. Ethanol concentration profile

Ethanol concentration generally increases until a fluctuating value is reached. At a time of 24 hours until the end of the run, the measured ethanol concentration fluctuates. This trend is observed across all immobilization media as shown. Ethanol production rate in $\mathrm{mL}$ of ethanol per hour is calculated by multiplying the fermentation broth flow rate and the ethanol concentration.

$$
\text { Production Rate }\left.\right|_{t}=Q_{\text {average }} \times\left[\mathrm{C}_{2} \mathrm{H}_{5} \mathrm{OH}\right]_{t}
$$

Fig. 5 shows the plot of the production rate versus time showing a trend similar to the change in ethanol concentration.

Fluctuation is present but the plots generally approach a final value. Glucose concentration relative to time is plotted and the average for the two trials is shown in figure 6 .

As expected, glucose concentration decreases. For the continuous runs where the cells are immobilized in NDC, CA and in the free cell (FC) there are instances where the glucose concentration in the reactor increased. This could be the consequence of slight variations in the fermentation broth flow rate, the interference of an invading microorganism thus decreasing the activity of $S$. cerevisiae or a combination of both. But in general, the concentration of glucose dropped reflecting effective glucose consumption by the cells in the reactor. Fractional conversion is calculated based on the outlet glucose concentration. The variation of the glucose fractional conversion with time is illustrated in figure 7 .

The trend of the fractional conversion is coherent with the attained glucose concentration. As the glucose concentration dropped and remained below $10 \mathrm{~g} / \mathrm{L}$ the high fractional conversion is expected to be 0.9 . However, even though this showed that glucose is consumed in the reaction it does not necessarily mean that the consumed glucose is used for ethanol production. The high glucose consumption could simply be a reflection of cellular metabolism to biomass and further measures of the reaction performance must be performed. In terms of the relative effectiveness of each immobilization medium, even by graphical inspection there is no difference between each method of immobilization.

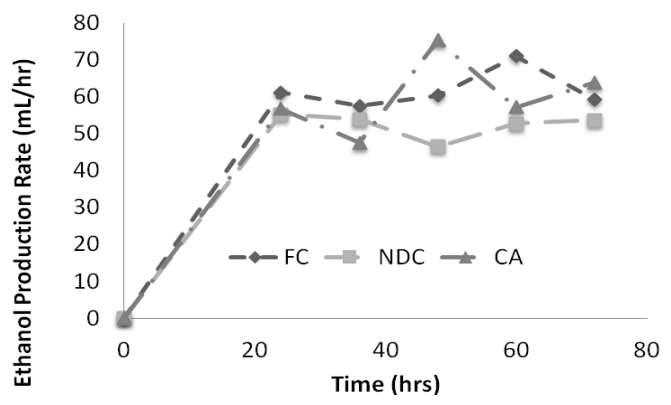

Fig. 5. Ethanol production rate

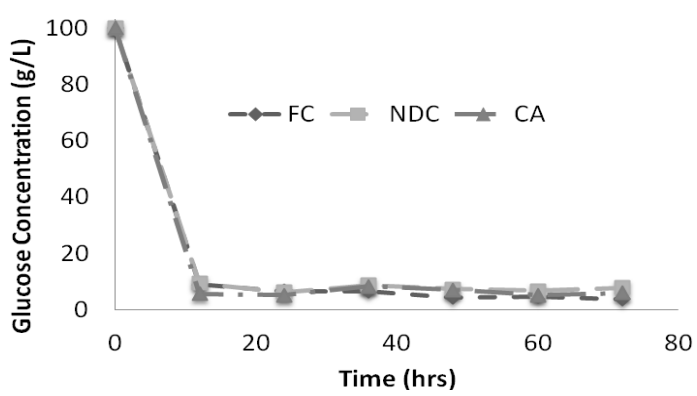

Fig. 6. Glucose concentration

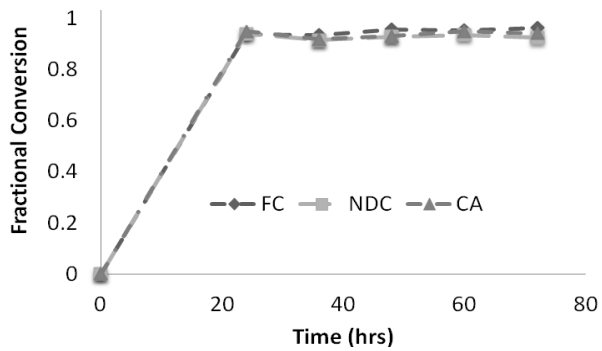

Fig. 7. Fractional conversion

A better means of measuring the reactor performance is by the use of yield. To calculate the yield, the ratio between the ethanol produced and the amount of sugar consumed is taken. This is a measure of how specific the reaction is towards ethanol production. Through the yield it is possible to check whether glucose consumption is used for ethanol production or for some other biological processes in the system. In figure 8 , yield as grams ethanol per grams of consumed glucose is plotted versus time.

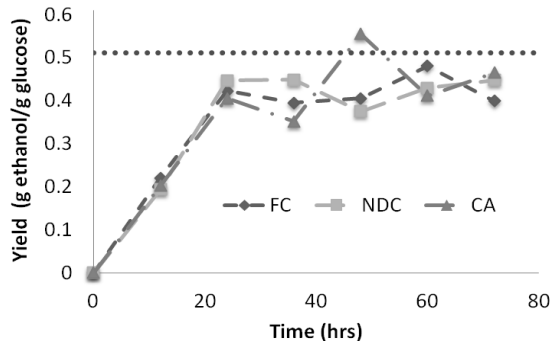

Fig. 8. Yield 
The yield follows a trend similar to ethanol concentration and production. For all methods the yield is between 0.3 and 0.5. The dotted line represents the theoretical yield for breaking down 1 mole of glucose into 2 moles of ethanol and 2 moles carbon dioxide. This has an exact value of 0.5114 and this is the highest possible attainable ethanol yield. A disparity is observed in CA immobilized cells at $\mathrm{t}=48 \mathrm{hrs}$ since the yield cannot be greater than the theoretical value. A percent yield of $95 \%$ is the highest attainable yield using a chemostat [5]. This corresponds to a value 0.4858 which is not exceeded by all other data points. The lower yield may be an effect of the fermentation conditions since although temperature is maintained at $30^{\circ} \mathrm{C}$ and the $\mathrm{pH}$ of the fermentation broth is buffered at $\mathrm{pH} 4$ the set-up is not completely anaerobic. Dissolved oxygen in the fermentation broth is not accounted for and may act as the initial oxygen acceptor until it is exhausted by $S$. cerevisiae cells, after which fermentation can proceed.

It is expected that the ethanol concentration would increase and gradually reach a steady state value. A steady state value is not achieved due to the fluctuating ethanol concentration but the expected trend is achieved. In many studies in ethanol fermentation, the outlet concentration does fluctuate thus other parameters also fluctuate. The mean values of ethanol concentration, production rate, glucose conversion and yield are summarized in table II, the percent difference between the value of the parameters for FC and NDC are in Table III and the percent relative standard deviation is in Table IV.

TABLE II: SUMMARY OF MEAN VALUES OF PARAMETERS DURING CONTINUOUS OPERATION

\begin{tabular}{|l|c|c|c|}
\hline \multicolumn{1}{|c|}{ Parameter } & Freecell & NDC & CA \\
\hline $\begin{array}{l}\text { Ethanol Concentration } \\
\text { (vol\%) }\end{array}$ & 5.103 & 5.093 & 5.250 \\
\hline $\begin{array}{l}\text { Ethanol production rate } \\
\text { (mL/hr) }\end{array}$ & 61.79 & 52.33 & 60.03 \\
\hline Fractional Conversion & 0.9487 & 0.9274 & 0.9373 \\
\hline $\begin{array}{l}\text { Yield } \\
\text { (g ethanol/g glucose) }\end{array}$ & 0.4202 & 0.4291 & 0.4375 \\
\hline
\end{tabular}

Table IV shows that the percent relative standard deviation in NDC is lower relative to CA. NDC immobilized cells are relatively more resistive to the uncontrolled changes in the cells environment. Immobilization with NDC generally resulted in the lowest ethanol concentration, production rate, fractional glucose conversion and yield. Percent difference is smaller for ethanol concentration, fractional conversion and yield but the production rate difference is significant at $12.827 \%$. For all samples, the average fractional conversion is very high with a minimum for NDC and a maximum for FC.

\section{Statistical Analysis}

The relationship between the immobilization medium and three factors: ethanol concentration, ethanol production rate, and fractional conversion are investigated. These factors are independently analyzed and the significance of the immobilization media is determined at three levels of immobilization medium, free cell, NDC and CA. The results of one-way ANOVA are summarized in Table V.

TABLE III: PERCENT DIFFERENCE BETWEEN NDC AND CA

\begin{tabular}{|l|c|}
\hline \multicolumn{1}{|c|}{ Parameter } & NDC-CA \% difference \\
\hline Ethanol Concentration & 2.990 \\
\hline Ethanol production rate $(\mathrm{mL} / \mathrm{hr})$ & 12.83 \\
\hline Fractional Conversion & 1.056 \\
\hline Yield & 1.920 \\
\hline
\end{tabular}

TABLE IV: PERCENT RELATIVE STANDARD DEVIATION

\begin{tabular}{|l|c|c|c|}
\hline \multicolumn{1}{|c|}{ Parameter } & Free cell & NDC & CA \\
\hline $\begin{array}{l}\text { Ethanol } \\
\text { Concentration } \\
\text { (vol\%) }\end{array}$ & 8.638 & 7.251 & 17.51 \\
\hline $\begin{array}{l}\text { Ethanol production } \\
\text { rate (mL/hr) }\end{array}$ & 8.587 & 6.495 & 17.11 \\
\hline $\begin{array}{l}\text { Fractional } \\
\text { Conversion }\end{array}$ & 24.44 & 1.051 & 1.388 \\
\hline $\begin{array}{l}\text { Yield } \\
\text { g ethanol/g } \\
\text { glucose) }\end{array}$ & 24.09 & 27.27 \\
\hline
\end{tabular}

TABLE V. SUMMARY OF ANOVA RESULTS (HO = NO SIGNIFICANT

\begin{tabular}{|l|c|c|c|c|}
\hline \multicolumn{1}{|c|}{ Parameter } & $\begin{array}{c}d f \\
\text { Between } \\
\text { Groups }\end{array}$ & $\begin{array}{c}d f \\
\text { Within } \\
\text { Groups }\end{array}$ & F & $\begin{array}{c}\text { P- } \\
\text { Value }\end{array}$ \\
\hline $\begin{array}{l}\text { Ethanol } \\
\text { Concentration }\end{array}$ & 2 & 12 & 0.09828 & $\begin{array}{c}0.907 \\
1\end{array}$ \\
\hline $\begin{array}{l}\text { Ethanol Production } \\
\text { Rate }\end{array}$ & 2 & 12 & 2.615 & $\begin{array}{c}0.114 \\
1\end{array}$ \\
\hline $\begin{array}{l}\text { Fractional } \\
\text { Conversion }\end{array}$ & 2 & 12 & 0.09828 & $\begin{array}{c}0.907 \\
1\end{array}$ \\
\hline Ethanol Yield & 2 & 15 & 0.02022 & $\begin{array}{c}0.980 \\
0\end{array}$ \\
\hline
\end{tabular}

For $\alpha=0.5$ or Fcrit $=3.885$, all the factors resulted to $\mathrm{F}<\mathrm{Fcrit}$ and $\mathrm{P}$-value $>\alpha$ and the null hypothesis is accepted. ANOVA analysis shows that the treatment means does not differ. The immobilization medium does not affect the measured parameters. The ethanol concentration, ethanol production rate, fractional conversion and yield of cells immobilized in CA are statistically similar with cells immobilized in NDC.

One noticeable advantage of cells immobilized in Nata de coco biocellulose is the structural integrity of the biocatalyst. Calcium alginate beads become soft and mushy after just 72 hours of continuous operation which is a disadvantage observed in several studies on continuous fermentation.

\section{CONCLUSION}

Four parameters are measured for the comparison of the relative performance of NDC and CA during continuous fermentation. Immobilization with CA resulted to the higher ethanol concentration at $5.25 \%$ by volume, production rate of $60.03 \mathrm{~mL} / \mathrm{hr}$, a 0.9373 fractional conversion and an ethanol yield of 0.4375 although the performance of yeast cells immobilized in NDC are not far behind with a percent difference ranging from $1.056 \%$ to $12.83 \%$.

The percent relative standard deviation of the mean values of the four parameters is determined. In all four parameters, the percent relative standard deviation in NDC is lower than in CA thus NDC showed better stability during the continuous operation.

These differences are quantified using one-way ANOVA and showed that the immobilization medium significantly 
affects the performance of a continuous fermentation process. Fermentation using the CA biocatalyst resulted to a higher average effluent ethanol concentration, production rate and conversion than NDC but the difference is statistically insignificant.

Statistical results showed that Nata de Coco is a promising immobilization medium because even though the resulting ethanol concentration, production rate, conversion and yield are lower, its performance is statistically similar to CA at reactor conditions optimized for CA. Performing the reaction at conditions optimized for NDC may decrease this difference.

The use of a horizontal bioreactor is expected to decrease the problem of the instability of $\mathrm{CA}$ but at the reactor conditions, breaking down of the gel biocatalyst is still observed. The advantage of NDC in terms of material strength and reusability should therefore be credited. The economic advantage of NDC is very significant since the cost of immobilization with CA (based on alginate alone) is 22.5 times that of NDC at the time of the experiment. Nata de Coco biocellulose therefore is a promising material for yeast cell immobilization.

The performance of NDC immobilized cells as a biocatalyst for continuous fermentation can be improved further at reactor conditions optimized for the said system. The void fraction, $\mathrm{pH}$, temperature and even dimensions of the reactor may be studied to optimize the process. The kinetics of the reaction may also identify a flow rate where continuous operation will be most efficient Several parameters in the methodology for cell immobilization may also be optimized including geometry, size, impeller speed or addition of polymers in biocellulose to further increase the cell loading capacity of NDC biocellulose and in turn an increased ethanol production rate

\section{REFERENCES}

T. I. Tech, "Production of biocellulose (bacterial cellulose, Retrieved January 14, 2011, from Tokyo Institute of Technology, Chemical Resources Laboratory. [Online]. Available: http://www.res.titech.ac.jp/ junkan/english/cellulose/,

[1] D. N. Nguyen, N. M. Ton, and V. V. Le, "Optimization of Saccharomyces cerevisiae immobilization in bacterial cellulose by 'adsorption- incubation' method," International Food Research Journal, pp. 59-64, 2009.

[2] S. Ramakrishna and R. Prakasham, Microbial fermentations with immobilized cells. [Online]. Available: http://www.ias.ac.in/currsci/jul10/articles17.htm

[3] P. J. Verbelen, D. P. D. Schutter, F. Delvaux, K. J. Vestrepen, and F. R. Delvaux, "Immobilized yeast cell systems for continuous fermentation applications," Biotechnol Lett, pp. 1515-1525, 2006.

[4] T. Shiotani and T. Yamane, "A Horizontal Packed-Bed Bioreactor to Reduce CO 2 Gas Holdup in the Continuous Production of Ethanol by Immobilized Yeast Cells," European Journal of Applied Microbiology and Biotechnology, pp. 96-101, 1981.

[5] T. C. Bhalla, M. Sharma, and N. N. Sharma, "Microbial production of Flavours and fragrances," [Online]. Available: http://nsdl.niscair.res.in/bitstream/123456789/648/1/MicrobialProduct ion.pdf

[6] G. C. Serafica, "Production of bacterial cellulose using a rotrating disk dilf bioreactor by Acetobacter Xylinum," Rensselaer Polytechnic Institute: New York, U.S.A, 1997.
[7] D. Taeymans, E. Roelans, and J. Lenges, "Comparison of different drying techniques for processing active dry yeast for use in fermentors with immobilized cells," in Food engineering and process applications. Vol. 1. Transport phenomena Food engineering and process applications. Vol. 1. Transport phenomena, M. 1. Maguer, and Jelen, Elsevier Applied Science Publishers Ltd, 1986, pp. 439-444.

[8] J. C. Ogbonna, Y. Amano, and K. Nakamura, "Elucidation of Optimum Conditions for Immobilization of Viable Cells by Using Calcium Alginate," Journal of Fermentation And Bioengineering, pp. 92-96, 1989.

[9] Wang, N. S., "Glucose Assay", retrieved November 22, 2010, from University of Maryland - A. James Clark School of Engineering: http://www.eng.umd.edu/ nsw/ench485/lab4a.htm

[10] D. W. Templeton, "Determination of Ethanol Concentration in Biomass to Ethanol Fermentation Supernatants by Gas Chromatography," Midwest Research Institute, Department Of Energy. National Renewable Energy Laboratory, 1994.

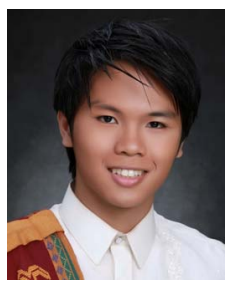

Charlimagne M. Montealegre graduated cum laude with a degree BS Chemical Engineering from the University of the Philippines, Diliman, Quezon City in April 2011. He is currently an instructor from the same university and is taking MS in Chemical Engineering from the same university. He is also a member of the Philippine Institute of Chemical Engineers.

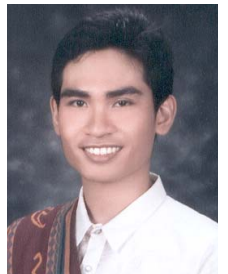

Jay R T. Adolacion graduated class 2007 from the University of the Philippines, Diliman with a degree of Bachelor of Science in Chemical Engineering. Since then he has been serving as a faculty member of the Department of Chemical Engineering from the same university. His research interests include biotechnology, and he is currently doing studies on adsorption systems.

Emerson R. Dionisio and Lawrence V. Sumera graduated from University of the Philippines Diliman Batch 2011 with a degree of Bachelor of Science in Chemical Engineering. Both of them were currently practicing chemical engineers in the Philippines.

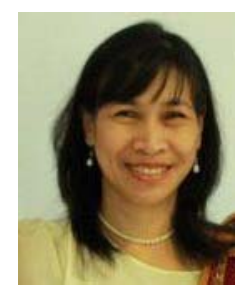

Rizalinda L. De Leon holds a Ph.D. in Chemical Engineering (2007), a M.S. in Energy Engineering (1989) and a B.S. in Chemical Engineering (1982) from the University of the Philippines in Diliman. She is currently the Chair of the Department of Chemical Engineering at the College of Engineering, University of the Philippines Diliman, where she serves as Assistant Professor. Borines, M.G., McHenry M.P. and de Leon, R.L., Integrated macroalgae production for sustainable bioethanol, aquaculture and agriculture in Pacific island nations, Biofuels, Bioproducts and Biorefining Volume 5, Issue 6, pages 599-608, November/December 2011. Borines, M.G., McHenry M.P, and de Leon, R.L. (2011), Bioethanol Production from farming non-food macroalgae in Pacific island nations: Chemical constituents, bioethanol yields, and prospective species in the Philippines, Renewable and Sustainable Energy Reviews 15: 4432-4435, doi: 10.1016/j-rser.2011.07.109Jan-Jezreel Saceda, Rizalinda L de Leon, Properties of Silica from Rice Husk and Rice Husk Ash and their Utilization for Zeolite Y Synthesis, Quim. Nova (2011). Among her research interests are processes for converting biomass into fuels, catalysts and other high value products, heat and mass transfer, nanofluid systems, phase change materials for cooling applications and photocatalysis for hydrogen production. R.L. de Leon is a member of the Philippine Institute of Chemical Engineers (PIChE) and the Philippine Association of Technical Education (PATE). She has beenthe holder of the Semirara Professorial Chair Award for the past three years and was given the Outstanding Professor Award for the School Year 2011-2012 by the University of the Philippines Diliman, College of Engineering. 